\title{
Karakteristik Air Tanah Akuifer Dalam Sekitar Tempat Pembuangan Sampah Terpadu (TPST) Bantar Gebang-Bekasi, Jawa Barat
}

\section{Characteristics of Deep Groundwater Aquifer in Bantar Gebang Sanitary Landfill Area-Bekasi, West Java}

\author{
SATRIO DAN EVARISTA RISTIN PUJIINDIYATI \\ Pusat Aplikasi Isotop dan Radiasi, Badan Tenaga Nuklir Nasional \\ Jl. Lebak Bulus Raya No. 49 Jakarta \\ satrio@batan.go.id
}

\begin{abstract}
A research has been performed regarding the deep groundwater aquifer at Bantar Gebang sanitary landfill area in Bekasi by using environmental isotopes and hydrochemistry. It was conducted by taking several deep groundwater samples. The aim of this research is to know the characteristics of deep groundwater to a possibility of interaction with leachate as the impact of waste disposal activities. Based on environmental isotopes of ${ }^{18} \mathrm{O}$ and ${ }^{2} \mathrm{H}$, the characteristics of deep groundwater aquifer could be divided into three groups. Firstly, most depleted concentration of ${ }^{18} \mathrm{O}$ and ${ }^{2} \mathrm{H}$ in $\mathrm{BG} 3$ site, indicated that the groundwater recharge from a higher elevation area. Secondly, the groundwater of BG2, BG4, BG7 and $B G 8$ that contained the most enriched isotope concentration, probably recharged from a lower elevation area. Thirdly, sites of BG1, BG5 and BG6 that had isotope concentrations ranging between the value in first and in second group, indicated that their groundwater origin located between both elevations. Moreover, the more enriched isotope value of BG5 and BG7 was not an indication of mixing with surface water of leachate. This also was supported by chemical data, but it mainly exhibited an evaporation process taking place. Tracing by isotope results mostly showed that all deep groundwater sites were not influenced by leachate plume generated by Bantar Gebang landfill. While, the results of ${ }^{14} \mathrm{C}$ showed that deep groundwater aquifer in Bantar Gebang generally moves from south to north and north-west direction.
\end{abstract}

Key words: groundwater charateristics, deep aquifer, environmental isotope, hydrochemistry, Bantar Gebang sanitary landfill

\begin{abstract}
ABSTRAK
Telah dilakukan penelitian air tanah akuifer dalam di sekitar TPST Bantar Gebang, Bekasi menggunakan pendekatan isotop alam dan kimia air. Penelitian dilakukan dengan mengambil sejumlah sampel air tanah akuifer dalam (kedalaman lebih dari $40 \mathrm{~m}$ ) di beberapa lokasi sumur bor sekitar TPST Bantar Gebang dan kemudian dianalisis konsentrasi isotop alam dan kimia airnya. Penelitian bertujuan untuk mengetahui karakteristik air tanah akuifer dalam di sekitar TPST Bantar Gebang terhadap kemungkinan interaksi dengan air lindi sebagai dampak aktivitas pembuangan sampah. Berdasarkan hasil analisis isotop alam ${ }^{18} \mathrm{O}$ dan ${ }^{2} \mathrm{H}$, karakteristik air tanah akuifer dalam dapat dibagi menjadi tiga kelompok sesuai perbedaan konsentrasi isotop alamnya. Pertama, air tanah B3 memiliki konsentrasi isotop alam ${ }^{18} \mathrm{O}$ dan ${ }^{2} \mathrm{H}$ paling miskin (depleted), diperkirakan berasal dari daerah imbuh (recharge) dengan elevasi relatif tinggi. Kedua, air tanah BG2, BG8, BG9, BG4 dan BG7 memiliki konsentrasi isotop alam ${ }^{18} \mathrm{O}$ dan ${ }^{2} \mathrm{H}$ paling kaya (enrich), diperkirakan berasal dari daerah imbuh dengan elevasi relatif rendah. Ketiga, air tanahBG6, BG1dan BG5 memiliki konsentrasi isotop alam ${ }^{18} \mathrm{O}$ dan ${ }^{2} \mathrm{H}$ berada diantara kelompok pertama dan kedua, diperkirakan daerah imbuhnya berada pada elevasi diantara keduanya.Namun demikian, baik berdasarkan hasil analisis isotop alam maupun kimia air, air tanah BG5 dan BG7 terindikasi telah mengalami proses evaporasi atau percampuran dengan air tanah dangkal atau air permukaan tetapi bukan dengan air lindi. Demikian pula dengan sampel air tanah lainnya, seluruhnya tidak mengalami interaksi dengan air lindi. Sementara itu, hasil ${ }^{14} \mathrm{C}$ menunjukkan bahwa aliran air tanah akuifer dalam bergerak dari selatan menuju utara dan barat-laut.
\end{abstract}

Kata kunci: karakteristik air tanah, akuifer dalam, isotop alam, kimia air, TPST Bantar Gebang 


\section{PENDAHULUAN}

\subsection{Latar Belakang}

Air tanah merupakan salah satu kebutuhan pokok bagi manusia, baik untuk kebutuhan air minum maupun untuk berbagai keperluan lainnya $^{(1)}$. Air tanah memiliki berbagai fungsi untuk menopang kehidupan manusia dan merupakan sumberdaya alam yang perlu dijaga kelestariannya. Dalam memanfaatkan air tanah ini masyarakat umumnya menggunakan pompa air $^{(2)}$. Namun seiring dengan pertambahan penduduk dan industri, kualitas dan kuantitas air tanah terus mengalami penurunan. Salah satu faktor penyebab penurunan kualitas air tanah yaitu kehadiran zat pencemar atau polutan di area pembuangan sampah. Lokasi tempat pembuangan akhir (TPST) sampah di area padat penduduk seperti TPST Bantar Gebang Bekasi akan memperburuk kualitas air tanah dalam jangka panjang.

TPST Bantar Gebang per harinya menerima $16.000 \mathrm{~m} 3$ dari $20.000 \mathrm{~m} 3$ sampah penduduk DKI Jakarta. Sampah yang dikirim biasanya berbentuk sampah kering (seperti plastik, kertas dan kardus) dan sampah basah (sayur mayur dan sampah rumah tangga lainnya). Sampah basah/organik inilah yang menghasilkan air lindi (leachate) dari proses pembusukan dan bisa mencemari air sumur penduduk sekitar ${ }^{(3,4)}$. Air lindi adalah cairan yang timbul akibat masuknya air eksternal ke dalam timbunan sampah, melarutkan dan membilas zat-zat terlarut. Cairan tersebut mengandung bahan organik yang tinggi sebagai hasil dekomposisi sampah dan juga berasal dari proses infiltrasi dari air limpasan ${ }^{(5,6)}$.

Seiring berjalannya waktu, air lindi ini akan terus menyebar dan meresap kedalam tanah dan akan berdampak terhadap pencemaran air tanah di sekitarnya. Air tanah dangkal yang umumnya banyak digunakan oleh penduduk akan mengalami dampak pencemaran yang paling signifikan dari migrasi polutan atau air lindi yang meresap kedalam tanah melalui pori-pori batuan. Pencemaran air lindi juga dikhawatirkan akan berdampak pada air tanah pada akuifer dalam yang ada di sekitar TPST Bantar Gebang.

\subsection{Tujuan Penelitian}

Kajian ilmiah mengenai karakteristik air tanah akuifer dalam di sekitar TPST Bantar Gebang bertujuan mengetahui hubungan air tanah akuifer dalam dengan air lindi, baik melalui pendekatan isotop alam maupun kimia air.

\section{BAHAN DAN METODE}

Metode isotop alam seperti ${ }^{18} \mathrm{O},{ }^{2} \mathrm{H}$ dan ${ }^{14} \mathrm{C}$ merupakan perunut atau tracer yang dapat diaplikasikan untuk menentukan karakteristik air di suatu lokasi termasuk asal-usul atau sumber polutan $^{(7,8,9)}$. Sedangkan data kimia air (anionkation) melalui diagram piper dapat melengkapi data isotop alam dalam mempelajari karakteristik air tanah tersebut ${ }^{(10)}$.

\subsection{Lokasi Penelitian}

Lokasi penelitian terletak di Kecamatan Bantar Gebang, Kota Bekasi yang mencakup tiga kelurahan yaitu Kelurahan Ciketing Udik, Kelurahan Cikiwul, dan Kelurahan Sumur Batu. Peta lokasi area penelitian dan titik pengambilan sampel air tanah akuifer dalam selengkapnya dapat dilihat pada Gambar 1.

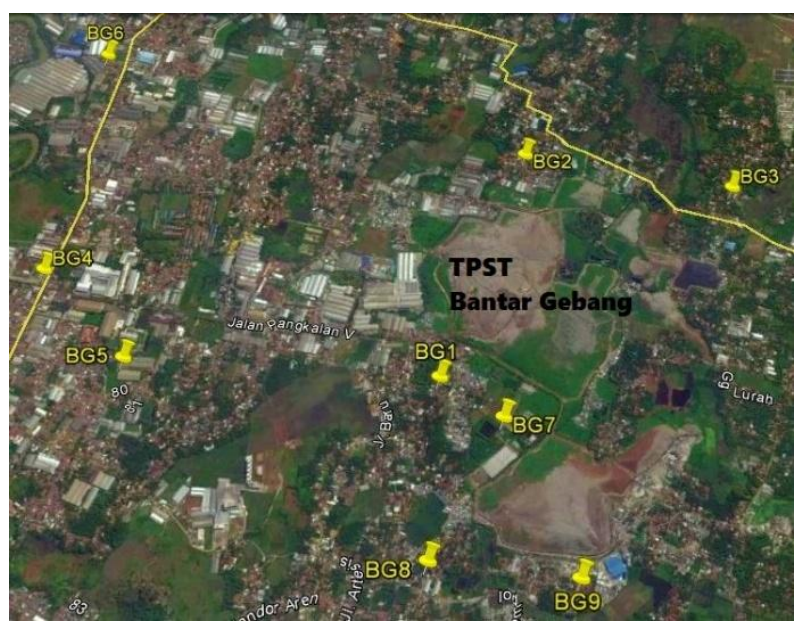

Gambar 1. Lokasi area penelitian dan titik pengambilan sampel air tanah akuifer dalam

\subsection{Bahan}

Bahan untuk pengambilan sampel dan analisis meliputi: botol plastik $50 \mathrm{ml}$, botol plastik 1 liter, vial gelas $21 \mathrm{ml}, \mathrm{FeSO}_{4}, \mathrm{NaOH}, \mathrm{BaCl}_{2}$, Praestol, $\mathrm{N}_{2}$-Cair, $\mathrm{HCl} 10 \%$, Ethanol, CarbosorbE dan Permafluor-E.

\subsection{Metode}

Sampel air untuk analisis isotop ${ }^{18} \mathrm{O}$ dan ${ }^{2} \mathrm{H}$ diambil langsung dari sumbernya menggunakan botol berkapasaitas $50 \mathrm{ml}^{(11)}$. Untuk mencegah penguapan, hindari adanya gelembung udara dalam botol.

Pengambilan sampel untuk analisis isotop ${ }^{14} \mathrm{C}$ dilakukan dengan cara mengambil sebanyak 60 liter sampel air langsung dari sumbernya dan dimasukkan kedalam ember berkapasitas 80 liter. Kemudian tuangkan kedalamnya 5 gram $\mathrm{FeSO}_{4}$ sambil dilakukan pengadukan. Selanjutnya tambahkan $40 \mathrm{ml} \mathrm{NaOH}, 500 \mathrm{ml}$ $\mathrm{BaCl}$ dan Praestol sambil terus dilakukan pengadukan hingga terbentuk endapan $\mathrm{BaCO}_{3}$. Endapan $\mathrm{BaCO}_{3}$ yang terbentuk dimasukkan kedalam botol berkapasitas 1 liter. Pengambilan 
sampel untuk analisis kimia air dilakukan dengan cara memasukkan sampel air kedalam botol berkapasitas 1 liter langsung dari sumbernya.

Analisis isotop alam ${ }^{18} \mathrm{O}$ dan ${ }^{2} \mathrm{H}$ dilakukan menggunakan alat liquid water isotope analyzer LGR (Los Gatos Research) DLT-100.Hasil perhitungan analisis isotop ${ }^{18} \mathrm{O}$ dan ${ }^{2} \mathrm{H}$ mengacu kepada standar internasional yaitu SMOW (Standard Mean Ocean Water) yang memiliki nilai ${ }^{18} \mathrm{O}$ dan ${ }^{2} \mathrm{H}$ sebesar $0 \%$ secara definitif. Hasil perhitungan analisis rasio ${ }^{18} \mathrm{O} /{ }^{16} \mathrm{O}$ dan ${ }^{2} \mathrm{H} /{ }^{1} \mathrm{H}$ dinyatakan dalam rasio relatif $(\delta)$ dengan satuan permil sebagai berikut ${ }^{(12,13)}$ :

$$
\delta=\frac{\left[\frac{18}{1{ }^{16} O}\right] \text { sampel }}{\left[\frac{18}{1{ }^{16} \mathrm{O}}\right] \text { standar }} \times 1000 \%
$$

dimana, $\left[{ }^{18} \mathrm{O} /{ }^{16} \mathrm{O}\right]_{\text {sampel: }}$ kelimpahan relatif ${ }^{18} \mathrm{O} /{ }^{16} \mathrm{O}$ $\left[{ }^{18} \mathrm{O} /{ }^{16} \mathrm{O}\right]_{\text {standar: }}: \begin{aligned} & \text { sampel } \\ & \text { kelimpahan } \\ & \text { standar }\end{aligned} \quad$ relatif ${ }^{18} \mathrm{O} /{ }^{16} \mathrm{O}$

Analisis isotop alam ${ }^{14} \mathrm{C}$ dilakukan dengan cara mereaksikan $\mathrm{BaCO}_{3}$ dengan $\mathrm{HCl} 10 \%$ sehingga diperoleh $\mathrm{CO}_{2}$ melalui rangkaian alat absorption line dalam kondisi vakum melalui reaksi berikut.

$$
\mathrm{BaCO}_{3}+2 \mathrm{HCl} \rightarrow \mathrm{BaCl}_{2}+\mathrm{H}_{2} \mathrm{O}+\mathrm{CO}_{2}
$$

$\mathrm{CO}_{2}$ yang di dalamnya terkandung isotop alam ${ }^{14} \mathrm{C}$ kemudian diserap menggunakan $30 \mathrm{ml}$ larutan campuran Carbosorb-E dan Permafluor-E dengan perbandingan $1: 1^{(14)}$. Kemudian sebanyak $21 \mathrm{ml}$ larutan tersebut diambil dan dituangkan ke dalam vial gelas $21 \mathrm{ml}$ untuk dilakukan proses pencacahan menggunakan Liquid Scintillation Analyzer Perkin Elmer 2910TR.

Analisis kimia air yang meliputi kation dan anion dilakukan menggunakan dua metode, yaitu ion kromatografi dan titrasi. Metode ion kromatografi menggunakan alat Chromatography Ion buatan Metrohm untuk analisis anion $(\mathrm{Cl}$, $\mathrm{SO}_{4}$ ) dan kation ( $\mathrm{Na}, \mathrm{K}, \mathrm{Ca}$ dan $\mathrm{Mg}$ ). Metode titrasi digunakan untuk analisis $\mathrm{HCO}_{3}$, sebagai titran digunakan $\mathrm{HCl}$ dan $\mathrm{NaOH}$.

\section{HASIL DAN PEMBAHASAN}

\subsection{Hasil Analisis Isotop Alam ${ }^{18} \mathrm{O}$ dan ${ }^{2} \mathrm{H}$}

Hasil analisis isotop alam $\left({ }^{18} \mathrm{O},{ }^{2} \mathrm{H}\right)$ seperti terlihat pada Tabel 1 menunjukkan bahwa secara umum air tanah akuifer dalam di sekitar TPST Bantar Gebang Bekasi berkisar antara -6,91\% hingga $-5,47 \%$ o untuk ${ }^{18} \mathrm{O}$ dan $-40,6 \%$ o hingga $35,0 \%$ ontuk ${ }^{2} \mathrm{H}$.

Tabel 1. Hasil analisis isotop alam ${ }^{18} \mathrm{O}$ dan ${ }^{2} \mathrm{H}$

\begin{tabular}{cccc}
\hline No. & Kode & $\delta^{18} \mathrm{O}(\%)$ & $\delta^{2} \mathrm{H}(\% \circ)$ \\
\hline 1 & BG1 & $-6,21$ & $-37,3$ \\
2 & BG2 & $-6,02$ & $-35,9$ \\
3 & BG3 & $-6,91$ & $-40,6$ \\
4 & BG4 & $-5,96$ & $-35,8$ \\
5 & BG5 & $-5,91$ & $-38,0$ \\
6 & BG6 & $-6,26$ & $-38,6$ \\
7 & BG7 & $-5,47$ & $-35,0$ \\
8 & BG8 & $-5,92$ & $-35,8$ \\
9 & BG9 & $-5,87$ & $-35,8$ \\
10 & IPAS-3 & $-5,98$ & $-23,9$ \\
\hline
\end{tabular}

Perbedaan konsentrasi isotop alam dari masing-masing sampel air mengindikasikan perbedaan asal-usul air tanah tersebut yang dapat dijelaskan melalui grafik hubungan $\delta^{2} \mathrm{H}$ vs $\delta^{18} \mathrm{O}$ seperti tampak pada Gambar $2^{(15,16)}$.

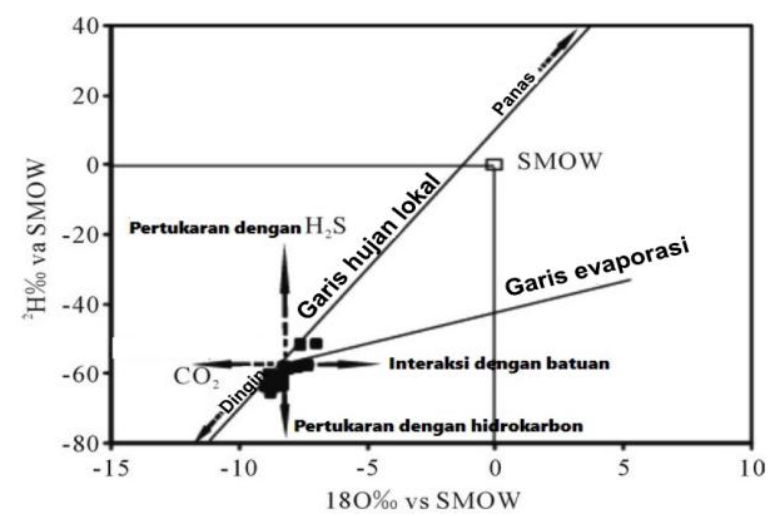

Gambar 2. Grafik hubungan $\delta^{2} \mathrm{H}$ vs $\delta^{18} \mathrm{O}$ air tanah dalam berbagai proses

Data isotop alam ${ }^{18} \mathrm{O}$ dan ${ }^{2} \mathrm{H}$ pada tabel di atas selanjutnya diplotkan dalam bentuk grafik hubungan $\delta^{2} \mathrm{H}$ vs $\delta^{18} \mathrm{O}$. Grafik hubungan $\delta^{2} \mathrm{H}$ vs $\delta^{18} \mathrm{O}$ air tanah akuifer dalam sekitar TPST Bantar Gebang ditunjukkan melalui Gambar 3. 


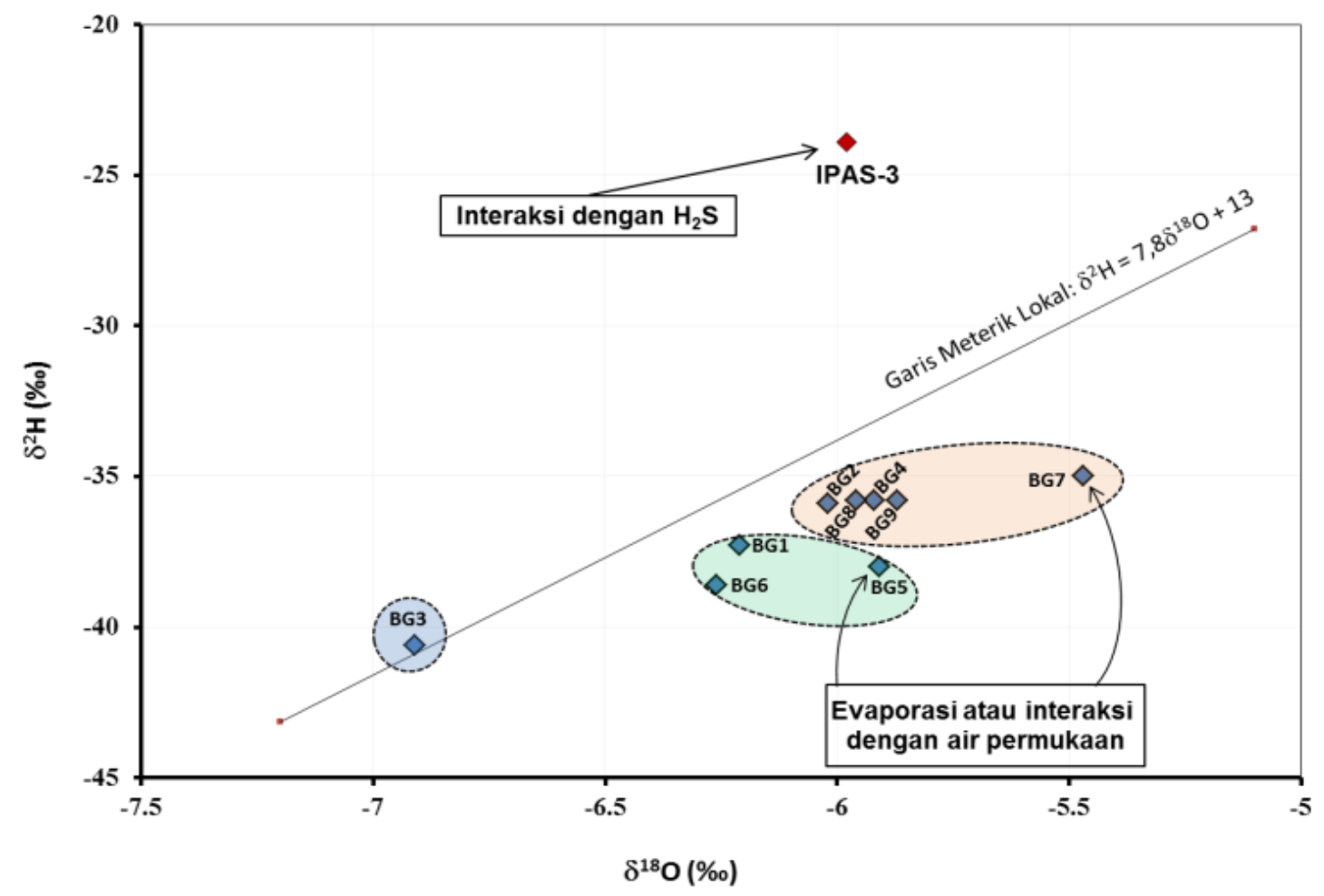

Gambar 3. Grafik $\delta^{2} \mathrm{H}$ vs $\delta^{18} \mathrm{O}$ air tanah akuifer dalam di sekitar TPST Bantar Gebang

Berdasarkan grafik tersebut, secara umum karakteristik air tanah akuifer dalam di sekitar TPST Bantar Gebang dapat dibagi menjadi tiga kelompok sebagai berikut:

1. Pertama, air tanah yang diambil dari sumur BG3 memiliki konsentrasi isotop alam ${ }^{18} \mathrm{O}$ dan ${ }^{2} \mathrm{H}$ paling miskin (depleted) dibandingkan dengan sampel air tanah lainnya dan diperkirakan berasal dari lokasi daerah imbuh (recharge) dengan elevasi relatif tinggi. Pada elevasi yang semakin tinggi, konsentrasi isotop stabil ${ }^{18} \mathrm{O}$ dan ${ }^{2} \mathrm{H}$ semakin depleted akibat efek ketinggian atau altitude effect ${ }^{(17)}$.

2. Kedua, sampel-sampel air tanah BG2, BG8, BG9, BG4 dan BG7 memiliki konsentrasi isotop alam ${ }^{18} \mathrm{O}$ antara $-6,02 \%$ hingga $-5,87$ $\%$ dan ${ }^{2} \mathrm{H}$ antara $-35,9 \%$ hingga $-35,8 \%$ atau memiliki konsentrasi isotop alam paling kaya (enrich) dibandingkan dengan sampelsampel air tanah dalam lainnya dan diperkirakan berasal dari lokasi recharge dengan elevasi relatif rendah. Namun demikian, khusus untuk sampel BG7 berdasarkan grafik tersebut memiliki karakter sebagai air tanah yang telah mengalami evaporasi atau mengalami interaksi dengan permukaan atau juga berinteraksi dengan air tanah akuifer dangkal di atasnya. Dengan demikian, BG7 dianggap sebagai air tanah yang telah mengalami percampuran dengan air tanah dangkal. Fenomena yang terjadi pada BG7 ini dapat divalidasi melalui data analisis kimia air. 3. Ketiga, air tanah BG6, BG1 dan BG5 memiliki konsentrasi isotop alam ${ }^{18} \mathrm{O}$ antara $-6,26 \%$ hingga $-5,91 \%$ dan ${ }^{2} \mathrm{H}$ antara $-38,6 \%$ hingga $-37,3 \%$ atau berada ditengah-tengah antara air tanah kelompok pertama dan kedua di atas. Hal ini pula mengindikasikan bahwa letak daerah recharge untuk ketiga lokasi air tanah ini diperkirakan berada pada elevasi diantara air tanah kelompok pertama dan air tanah kelompok kedua. Berdasarkan grafik tersebut terlihat pula bahwa untuk air tanah BG5 memiliki karakter sebagai air tanah yang mengalami evaporasi atau mengalami interaksi dengan air permukaan atau juga mengalami interaksi dengan air tanah dangkal di atasnya.

Berdasarkan grafik pada Gambar 3 di atas terlihat juga bahwa sampel air yang berasal dari lokasi instalasi pengolahan akhir sampah (IPAS) atau air lindi memiliki karakter sebagai air yang mengalami interaksi dengan senyawa $\mathrm{H}_{2} \mathrm{~S}$, yaitu interaksi antara isotop ${ }^{2} \mathrm{H}$ dari air dengan isotop ${ }^{2} \mathrm{H}$ dari $\mathrm{H}_{2} \mathrm{~S}$. Hal ini dapat dipahami, karena limbah organik yang dihasilkan di area pembuangan sampah banyak menghasilkan senyawa $\mathrm{H}_{2} \mathrm{~S}$ sebagai hasil dari proses pembusukan sampah-sampah organik. Dari grafik tersebut, terlihat pula bahwa tidak ada satu pun sampel air tanah mengalami interaksi dengan air lindi. 


\subsection{Hasil Analisis Isotop Alam ${ }^{14} \mathrm{C}$}

${ }^{14} \mathrm{C}$ merupakan isotop radioaktif alam yang digunakan untuk penentuan umur atau sering disebut radiocarbon dating. Jika yang akan ditentukan umurnya berupa air tanah, isotop ${ }^{14} \mathrm{C}$ ini sering pula disebut sebagai groundwater dating (18). Aplikasi isotop ${ }^{14} \mathrm{C}$ dalam penelitian air tanah umumnya digunakan untuk menentukan umur air tanah yang memiliki kedalaman lebih dari $40 \mathrm{~m}$ di bawah permukaan tanah setempat (dbpts) atau sering disebut pula sebagai air tanah akuifer dalam.

Hasil analisis isotop alam ${ }^{14} \mathrm{C}$ air tanah akuifer dalam sekitar TPST Bantar Gebang ditunjukkan melalui Tabel 2.

Tabel 2. Hasil analisis isotop alam ${ }^{14} \mathrm{C}$

\begin{tabular}{cccc}
\hline No. & Kode & $\begin{array}{c}\text { Percent } \\
\text { Modern Carbon } \\
\text { (PMC) }\end{array}$ & $\begin{array}{c}\text { Umur } \\
\text { (tahun *BP) }\end{array}$ \\
\hline 1 & BG1 & 36,73 & 8279 \\
2 & BG2 & 39,69 & 7639 \\
3 & BG3 & 54,63 & 4998 \\
4 & BG4 & 37,74 & 8057 \\
5 & BG5 & 84,96 & 1348 \\
6 & BG6 & 42,24 & 7124 \\
7 & BG7 & 89,21 & 944 \\
8 & BG8 & 61,62 & 4003 \\
9 & BG9 & 56,29 & 4751 \\
\hline
\end{tabular}

BP : before present $=1950$

Berdasarkan hasil analisis isotop alam ${ }^{14} \mathrm{C}$ tersebut, umur air tanah yang berasal dari sekitar TPST Bantar Gebang bervariasi antara 1300 tahun BP hingga 8200 tahun BP (BP: before present $=1950)$. Variasi ini ada hubungannya dengan asal-usul air tanah seperti yang telah dijelaskan pada pembahasan hasil analisis isotop alam ${ }^{18} \mathrm{O}$ dan ${ }^{2} \mathrm{H}$ di atas. Umur air tanah BG7 dan BG5 masing-masing sebesar 944 tahun BP dan 1348 tahun BP tergolong air tanah berumur muda. Jika dikoreksi dengan efek reservoir sebesar 85 PMC (percent modern carbon), maka air tanah tersebut dapat dikatakan memiliki umur Modern. Hasil umur BG5 ini ternyata sesuai dengan karakter air tanah sebagaimana ditunjukkan melalui grafik isotop ${ }^{2} \mathrm{H}$ vs ${ }^{18} \mathrm{O}$ yang mengindikasikan bahwa air tanah tersebut berhubungan atau berinteraksi dengan air tanah dangkal atau air permukaan. Demikian halnya dengan air tanah BG7 yang juga berumur muda, mengindikasikan adanya evaporasi atau mengalami interaksi dengan air permukaan dan fenomena ini sesuai dengan hasil analisis isotop alam ${ }^{18} \mathrm{O}$ dan ${ }^{2} \mathrm{H}$ seperti telah ditunjukkan melalui grafik hubungan isotop ${ }^{2} \mathrm{H}$ vs ${ }^{18} \mathrm{O}$.

Sebagaimana telah diperlihatkan dalam grafik isotop alam ${ }^{2} \mathrm{H}$ vs ${ }^{18} \mathrm{O}, \mathrm{BG} 8, \mathrm{BG} 9, \mathrm{BG} 2$ dan BG4 memiliki kesamaan asal recharge, tetapi berbeda umur airnya. BG8 dan BG9 yang terletak di selatan TPST memiliki umur air antara 4000 - 4700 tahun BP atau lebih muda dibandingkan dengan BG2 dan BG4 dengan umur antara 7600 - 8000 tahun BP yang terletak di sebelah utara TPST. Fenomena ini menunjukkan bahwa arah aliran air tanah tersebut bergerak dari selatan menuju utara dan barat-laut. Demikian pula halnya dengan BG6 dan $B G 1$, dari grafik isotop ${ }^{2} \mathrm{H}$ vs ${ }^{18} \mathrm{O}$ tersebut terindikasi berasal dari recharge yang sama dengan umur air masing-masing 7124 tahun BP dan 8279 BP. Umur air BG6 lebih muda dari BG1 yang mengindikasikan pergerakan air tanah dari selatan menuju arah barat-laut. Khusus untuk sampel BG3 yang memiliki umur sekitar 5000 tahun BP, sebagaimana dijelaskan di atas dianggap berasal dari recharge yang relatif jauh dan diperkirakan memiliki perbedaan akuifer atau perbedaan lintasan batuan yang dilaluinya jika dibandingkan sampel air tanah lainnya. Dengan demikian perbedaan daerah recharge dan lintasan batuan yang dilaluinya menyebabkan perbedaan umur air dari masingmasing sampel air tanah tersebut.

Arah aliran air tanah akufer dalam di sekitar TPST Bantar Gebang berdasarkan hasil analisis isotop alam ${ }^{18} \mathrm{O},{ }^{2} \mathrm{H}$ dan ${ }^{14} \mathrm{C}$ selengkapnya dapat dilihat pada Gambar 4. Pada peta tersebut, arah aliran air tanah akuifer dalam diperlihatkan melalui tanda panah warna hijau.

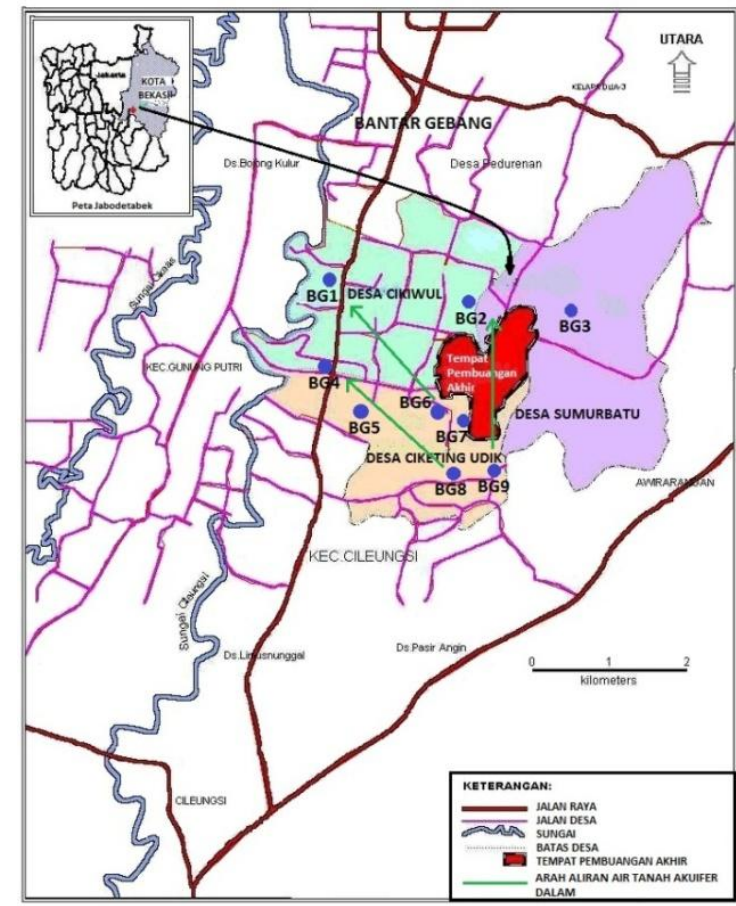

Gambar 4. Peta arah aliran air tanah akuifer dalam sekitar TPST Bantar Gebang 


\subsection{Hasil Analisis Kimia Air}

Tabel 3 dan Tabel 4 memperlihatkan hasil analisis kimia air yang meliputi anion $\mathrm{Cl}, \mathrm{SO}_{4}$, $\mathrm{HCO}_{3}$ dan kation $\mathrm{Na}, \mathrm{K}, \mathrm{Ca}, \mathrm{Mg}$.

Tabel 3. Hasil analisis kimia air: anion

\begin{tabular}{c|l|r|r|r}
\hline No. & \multirow{2}{*}{ Kode } & \multicolumn{1}{c|}{$\mathrm{Cl}$} & \multicolumn{1}{c}{$\mathrm{SO}_{4}$} & \multicolumn{1}{|c}{$\mathrm{HCO}_{3}$} \\
\cline { 3 - 5 } & & \multicolumn{3}{|c}{$(\mathrm{ppm})$} \\
\hline 1 & BG1 & 2,62 & 0,59 & 39,00 \\
\hline 2 & BG2 & 8,04 & 0,59 & 154,76 \\
\hline 3 & BG3 & 12,69 & 0,59 & 155,26 \\
\hline 4 & BG4 & 1,81 & 7,00 & 45,40 \\
\hline 5 & BG5 & 52,40 & 6,70 & 42,60 \\
\hline 6 & BG6 & 8,04 & 0,59 & 173,00 \\
\hline 7 & BG7 & 10,10 & 0,59 & 24,40 \\
\hline 8 & BG8 & 7,19 & 0,59 & 138,01 \\
\hline 9 & BG9 & 8,04 & 0,59 & 141,46 \\
\hline 10 & IPAS-3 & 2253 & 9,55 & 9547 \\
\hline
\end{tabular}

Tabel 4. Hasil analisis kimia air: kation

\begin{tabular}{r|l|l|r|r|r}
\hline No. & \multirow{2}{*}{ Kode } & \multicolumn{1}{|l|}{$\mathrm{Na}$} & \multicolumn{1}{c|}{$\mathrm{K}$} & \multicolumn{1}{c|}{$\mathrm{Ca}$} & \multicolumn{1}{c}{$\mathrm{Mg}$} \\
\cline { 3 - 6 } & & \multicolumn{4}{|c}{$(\mathrm{ppm})$} \\
\hline 1 & BG1 & 57,65 & 4,10 & 18,80 & 2,78 \\
\hline 2 & BG2 & 76,06 & 4,19 & 11,27 & 3,22 \\
\hline 3 & BG3 & 68,38 & 4,50 & 18,26 & 4,10 \\
\hline 4 & BG4 & 76,63 & 3,58 & 3,28 & 0,86 \\
\hline 5 & BG5 & 17,57 & 1,75 & 46,72 & 10,33 \\
\hline 6 & BG6 & 81,25 & 3,27 & 15,18 & 2,84 \\
\hline 7 & BG7 & 9,78 & 2,62 & 29,93 & 8,42 \\
\hline 8 & BG8 & 61,51 & 3,24 & 13,59 & 3,56 \\
\hline 9 & BG9 & 57,39 & 3,27 & 15,99 & 5,01 \\
\hline 10 & IPAS-3 & 4504 & 4349 & 21,58 & 4,81 \\
\hline
\end{tabular}

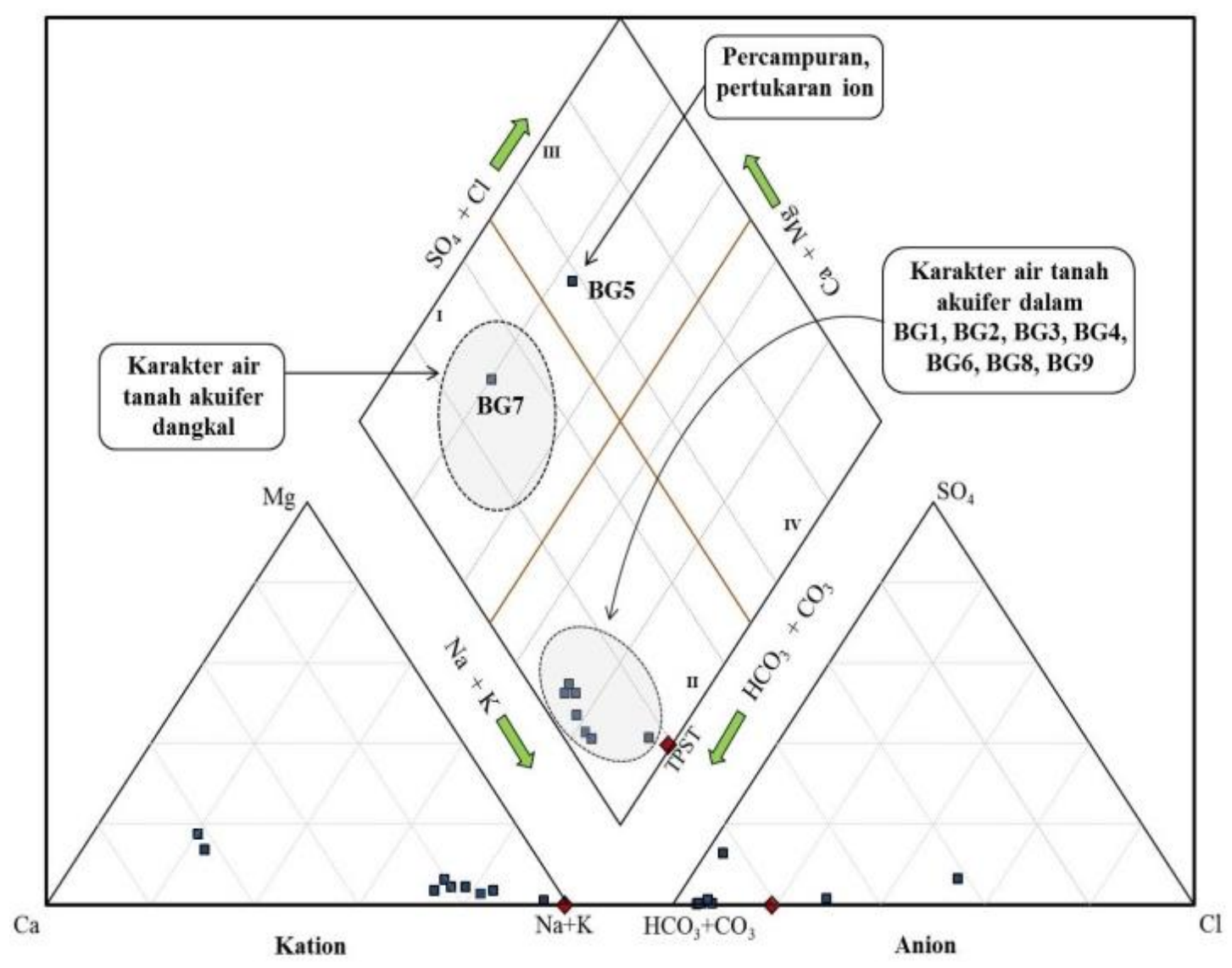

Gambar 5. Diagram piper sampel air tanah akuifer dalam di sekitar TPST Bantar Gebang

Data kimia air kemudian diplotkan dalam diagram piper untuk melihat karater air dari setiap sampel air tanah. Berdasarkan diagram piper sebagaimana ditunjukkan Gambar 5 terlihat bahwa BG5 berada di kuadran III dengan tipe air $\mathrm{CaNaHCO}_{3}$ yang mengindikasikan adanya pertukaran ion akibat proses percampuran dengan air yang terdapat di sekitarnya.
Sementara itu, BG7 berada di kuadran I dengan tipe air $\mathrm{CaHCO}_{3}$ yang menunjukkan karakter sebagai air tanah dangkal. Sedangkan sampel air tanah lainnya berada di kuadran II yang menunjukkan karakter sebagai air tanah akuifer dalam dengan tipe air $\mathrm{NaHCO}_{3}$, namun sebagian besar lebih dominan $\mathrm{HCO}_{3}{ }^{(19)}$. Sampel air IPAS-3 berada di kuadran II dengan tipe air $\mathrm{NaHCO}_{3}$, 
namun lebih dominan $\mathrm{Na}$. Walaupun memiliki tipe air yang sama dengan sebagian besar air tanah dalam, sampel IPAS-3 sebenarnya merupakan air lindi yang berada di permukaan.

\section{KESIMPULAN}

Karakteristik air tanah akuifer dalam di sekitar TPST Bantar Gebang, Bekasi, Jawa Barat berdasarkan hasil analisis isotop alam ${ }^{18} \mathrm{O},{ }^{2} \mathrm{H}$, ${ }^{14} \mathrm{C}$ dan kimia air (anion-kation) menunjukkan bahwa seluruh sampel air tanah tidak berinteraksi atau berhubungan dengan air lindi. Dari seluruh sampel air tanah, kecuali BG5 dan BG7 masih menunjukkan karakter sebagai air tanah akuifer dalam. BG5 dan BG7 terindikasi mengalami interaksi dengan air tanah dangkal atau permukaan yang berasal dari sekitarnya. Hal ini didukung dengan hasil analisis isotop alam ${ }^{14} \mathrm{C}$ yang menghasilkan umur air tanah muda. Disamping itu, dari hasil analisis isotop alam ${ }^{14} \mathrm{C}$ (groundwater dating) juga menunjukkan bahwa arah aliran air tanah akuifer dalam di sekitar TPST Bantar Gebang secara umum bergerak dari selatan menuju utara dan baratlaut.

\section{PERSANTUNAN}

Penelitian ini sebagian dibiayai melalui dana DIPA 2015. Penulis mengucapkan terimakasih kepada analis isotop alam dan kimia di lab Hidrologi, Pusat Aplikasi Isotop dan Radiasi BATAN.

\section{DAFTAR PUSTAKA}

1. Satrio, Hendarmawan, M. Sapari, \& E. Ristin, (2015), Karakteristik Air Tanah Dangkal Kota Semarang Pada Musim Penghujan Berdasarkan Pendekatan Isotop Stabil $\left({ }^{18} \mathrm{O},{ }^{2} \mathrm{H}\right)$ dan Kimia Air, Jurnal IImiah Aplikasi Isotop dan Radiasi, 11(1), 73-86.

2. Satrio, Syafalni dan P. Sidauruk, (2014), Studi Karakteristik Air Tanah Dangkal Sekitar TPST Bantar Gebang, Bekasi, dengan Metode Sumur Tunggal dan Ganda, Jurnal IImiah Aplikasi Isotop dan Radiasi, 10(1), 1 - 10.

3. Rosid, S., R.N. Koesnodo, dan P. Nuridianto, (2011), Estimasi Aliran Air Lindi TPST Bantar Gebang Bekasi Menggunakan Metoda SP, Jurnal Fisika 1(2), 54-58.

4. Fernando, A. (2011), Analisis Kelayakan TPST Regional untuk Wilayah Pelayanan Kota Jakarta Barat, Kabupaten Tangerang, Kota Tangerang, dan Kabupaten Serang Ditinjau dari Pemilihan Teknologi Pengolahan Sampah, Pembiayaan, dan
Institusi, Jurnal Sains dan Teknologi Lingkungan, 3(1), 052 - 065.

5. Royadi. (2006), Analisis Pemanfaatan TPST Sampah Pasca Operasi Berbasis Masyarakat: Studi Kasus TPST Bantar Gebang, Bekasi, Sekolah Pascasarjana Intitut Pertanian Bogor.

6. Fahria, (2012), Munawar dan Laksmono, R., Kinetika Biodegradasi Zat Organik pada Air Limbah Sampah (Lindi), Jurnal IImiah Teknik Lingkungan, 4(2), 111-118.

7. Tazioli, A., (2011), Landfill investigation using tritium and isotopes as pollution tracers, Jurnal AQUA mundi, DOI 10.4409/Am-0330-11-0030, 083-092.

8. Yidana, S.M., (2013), The Stable Isotope Characteristics of Groundwater in the Voltaian Basin - An Evaluation of the Role of Meteoric Recharge in the Basin, Journal of Hydrogeology \& Hydrologic Engineering, 2(2), 1-10.

9. Sharma, B., R. Singh, P. Singh, D.P. Uniyal, and R. Dobhal .(2015), Water Resource Management through Isotope Technology in Changing Climate, American Journal of Water Resources, 3(3), 86-91.

10. Al-Khatib, M., (2011), Hydro-Geochemical Characteristics of Groundwater beneath the Gaza Strip, Journal of Water Resource and Protection, 3(5).

11. Bhandary, H., K. Al-Fahad and M. AlSenafy, (2013), Assesment of Water Rise Problem Using Environmental Isotopes at Al-Qurain Residence Area, Kuwait, Seventeenth International Water Technology Conferency, IWTC17.

12. Hendrikson, N., J. Karhu, andP. Niinikoski, (2014), ${ }^{18} \mathrm{O},{ }^{2} \mathrm{H}$ and ${ }^{3} \mathrm{H}$ Isotopic Composition of Precipitation and Shallow Groundwater in Olkiluoto, POSIVA OY, Fl-27160 EURAJOKI, FINLAND.

13. Allen, J.R. Brooks, R.F. Keim, B.J., Bon, and J.J. McDonnel (2013), The role of pre-event canopy storage in throughfall and stemflow by using isotopic tracers, Ecohydrology, DOI: 10.1002/eco.1408.

14. Canducci, C.,P.. Bartolomei, G. Magnani, A. Rizzo, A. Piccoli, L.Tositti, and M. Esposito, M. (2013), Upgrade of The $\mathrm{CO}_{2}$ Direct Absorption Method for Low-Level ${ }^{14} \mathrm{C}$ Liquid Scintillation Counting, Proceeding Of the $21^{\text {st }}$ International Radiocarbon Conference, 55(23), 260-267. 
15. Edirisinghe, E. A. N. V., H. M. T. G. A Pitawala,., H.A. Dharmagunawardhane and R.L Wijayawardane, (2014), Isotopic Variation In Natural Water And Groundwater Recharge Conditions In The Kalaoya Basin, Sri Langka, Ceylon Journal of Science (Physical Sciences), 18, 09-16.

16. Edoulati, N., S. Boutaleb, I. Bettar, and A. Ouchbani, (2013), Contributions of Chemical and Isotopic Tools for Understanding the Groundwater Modes Recharge and Flow in the Lower Cretaceous Aquifer in the Moroccan Sahara, Journal of Water Resource and Protection, 5(2), 183-199.
17. Koeniger, P., M. Toll, and T. Himmelsbach, (2016), Stable isotopes of precipitation and spring waters reveal an altitude effect in the Anti-Lebanon Mountains, Syria, Hydrological Processes, 30, 2851-2860.

18. IAEA. (2013), Isotope Methods For Dating Old Groundwater, Marketing and Sales Publishing Section IAEA, STI/PUB/1587, Vienna, Austria.

19. Xing, L., H. Guo, and Y. Zhan, (2013), Groundwater hydrochemical characteristics and processes along flow path in the North China Plain, Journal of Asian Earth Sciences, 70-71, 250-264. 